brazilianpoliticalsciencereview

BOOK REVIEW

\title{
In Search of the Latin American Variety of Capitalism*
}

\author{
by Tomás Bril-Mascarenhas \\ Ph.D. Candidate, University of California, Berkeley, United States
}

(SCHNEIDER, Ben Ross. Hierarchical Capitalism in Latin America: Business, Labor, and the Challenges of Equitable Development. Cambridge: Cambridge University

Press, 2013)

he classical endeavor of comparing national models of capitalism has
fortunately returned to the center of political science. Its resurgence can be attributed to the publication of Varieties of Capitalism (HALL and SOSKICE, 2001) and the multiple debates triggered by this book. Almost a decade later, Ben Ross Schneider has published Hierarchical Capitalism in Latin America, the first comprehensive and systematic effort to apply the framework of $\mathrm{VoC}$ to Latin America. This inspiring book feeds the growing community of scholars who are calling for a renovation of the traditionally vibrant but recently stagnant field of Latin American political economy (LUNA, MURILLO, and SCHRANK, 2014). The book presents new arguments and empirical evidence to support the critical diagnosis that if we do not strengthen the study of business actors and how politics and markets are mutually shaped, we will continue to miss extremely important political processes and outcomes in this region.

Schneider's book utilizes institutional complementarities-VoC's core and most elegant analytical device-to build the novel concept of hierarchical market economy (HME), which, he argues, defines the distinctive nature of capitalism in Latin America. Four elements characterize HMEs: diversified business groups, multinational corporations (MNCs), segmented labor markets, and low levels of education and vocational skills. The book dedicates one chapter to each of the four 
dimensions of HMEs. These mutually reinforcing attributes result in a tight equilibrium that has proved resilient over time, even through the regional transition from a state-led import substitution industrialization model to a postneoliberal setting.

Among many institutional complementarities, the continued prominence of MNCs in Latin America-and their practice of importing the innovation they generate in their home countries-increases incentives for domestically-owned diversified business groups to specialize in lower-technology sectors, which in turn reduces these grupos' demand for skilled labor. The low level of skills in these economies further strengthens the disincentives of both domestic business groups and MNCs to conduct higher-technology investment. As a result, Latin America's comparative institutional advantage lies in simple manufacturing and commodities, which contrasts with both the radical and incremental types of innovation enabled by the institutions of Liberal Market Economies (LME) and Coordinated Market Economies (CME), respectively.

In its extension of the $V o C$ framework to the developing world, Hierarchical Capitalism in Latin America begins to address, within the limits of this region, the shortcomings that characterize the original framework, i.e., its sidelining of the state's role in contrasting types of capitalism, its apolitical character, and its inattention to history. By reflecting on how these three dimensions play out in defining HMEs, Schneider's book has the additional benefit of suggesting to scholars studying industrialized nations how to overcome $V o C^{\prime}$ s limitations in understanding the origins and changes of LMEs and CMEs over time.

Probably only those who face the rather lonely challenge of conducting research on the interaction of business and politics in Latin America-within an academic community where other interest groups such as social movements and labor receive significantly higher levels of attention-will be able to fully appreciate the achievements of this book. The breadth of case knowledge shown in a work that presents original research covering six countries (Argentina, Brazil, Chile, Colombia, Mexico, and Peru) is impressive. It is these very same scholars who will need to conduct more fine-tuned readings of Schneider's book in progressing to the next stages of research that this work may motivate. There are 
two elements of Hierarchical Capitalism in Latin America that may be critically assessed to improve our future findings.

First, parsimony comes at the risk of losing too much texture. Subsuming a majority of Latin America's political economies under the single conceptual umbrella of HME is a provocative endeavor. However, some may be concerned that variation within the region across national models of capitalism is too important to be muted. The question is not whether such within-HME variation is large but if what we gain analytically is more than what we lose. It suffices here to mention that a part of the book's success in making the pro-lumping (or anti-splitter) case arises from a reproduction of what many believe to be $V o C^{\prime}$ 's original sin: leaving the state out of the picture. While, as mentioned above, Schneider does make an effort to recover the state's role in the latter parts of the book, the state is rather absent in the construction of the HME logic. In a region where-especially in the period of post-market-oriented reform and commodity boom period-states are doing remarkably different things (from Chile's neoliberal continuity to Brazilian neodevelopmentalism, to forms of neostatism in Argentina), the task of inquiring into the nature of Latin American capitalism may suffer by the decision to cover such a large set of cases through a single concept. Even a firm-centric analysis may suffer.

A second element of potential concern is how the book deals with the relation between financial systems and investment finance. In the original $V o C$ agenda, finance is seen in a narrow perspective. The focus is on how it affects the concentration or dispersion of firms' share ownership, as well as on how that, in turn, shapes the incentives of major stakeholders in a country's corporations. The application of this corporate-governance-anchored approach to financial systems leads Schneider to emphasize that a defining feature of the region's variety of capitalism is the absence of competitive markets for corporate control. This book's placement of this factor at the center of a new understanding of capitalism in Latin America is an invaluable contribution. At the same time, the decision to use this particular lens to observe investment finance leads to an underestimation of the influence that increasingly deep domestic financial systems have on big business strategies in some Latin American countries. 
While equity concentration characterizes Latin America's largest firms across countries-giving, as Schneider argues, a hierarchical flavor to this type of capitalism - the development of capital and credit markets in some countries and their lack in others affects the distinctive functioning of capitalism within the set of HMEs (BRIL-MASCARENHAS, 2015). Chile, for instance, has evolved toward a financial system marked by a particularly large long-term corporate debt market, a deep equity market for a country of its size, and the availability of pension-fundfueled long-term bank credit for large firms. Today's Brazil is characterized by an equity market significantly more developed than that of the past and by a BNDESdependent but highly relevant long-term loan market for firms. The fact that none of the HMEs has transitioned to an US-like financial system, where corporate ownership is atomized, should not obstruct our ability to identify the consequences of these developments in the financial arena for a firm-centric analysis of Latin American capitalism. Critical recent phenomena that are reshaping capitalism in this region, such as the emergence of Latin American multinational corporations, are closely related to these new trends in domestic financial systems (see, for instance, FINCHELSTEIN, 2010). The facts that prototypical diversified business groups that historically never went public, e.g., Votorantim, are launching IPOs for some of their member firms, and that grupos more generally-especially those whose sales are concentrated in the domestic markets-need to tap domestic sources of finance, suggest that the image of large business groups that exclusively rely on retained earnings to self-finance their large investment projects may not continue to accurately depict how grupo CFOs actually operate in the field.

Hierarchical Capitalism in Latin America is a landmark contribution for many reasons. The book shines in its capacity to identify the core features of capitalism in this region, in abstracting a logic of how different parts fit together, in establishing hierarchy as an orienting concept, and in fruitfully deploying the analytical machinery of $V o C$ to understand not only HMEs but also several traps that affect development in Latin America. In doing so, Schneider carefully handles an impressive amount of case knowledge that provides roots for this framework. The back and forth between deductive and inductive work is a particularly remarkable achievement. If this were not enough, the book also accomplishes 
possibly the most lasting impact of any outstanding academic work: it shows us what we still do not know and why discovering it is quite urgent. In particular, we still do not know enough regarding the issues on which Schneider speculates in Chapter 7, for example, how and under what circumstances business actors succeed or fail to translate their preferences into public policy. As with all major works, Schneider's work bears a convincing message on how current academic debates need to be reoriented and what agendas deserve more resources and attention than they are receiving. Undoubtedly, this is a powerful way of pushing us forward.

Revised by Cabo Verde

\section{References}

BRIL-MASCARENHAS, Tomás (2015), The Politics of Financial Systems in Latin America. Unpublished manuscript.

FINCHELSTEIN, Diego (2010), Different States, Different Internationalizations: An Analysis of the Process of Firms' Internationalization in Argentina, Brazil and Chile. PhD Dissertation. Northwestern University.

HALL, Peter A. and SOSKICE, David W. (2001), Varieties of Capitalism: The Institutional Foundations of Comparative Advantage. Oxford, New York: Oxford University Press.

LUNA, Juan Pablo; MURILLO, M. Victoria and SCHRANK, Andrew (2014), Latin American Political Economy: Making Sense of a New Reality. Latin American Politics and Society. Vol. 56, № 01, pp. 03-10. 